\title{
分岐系統の回転機による回線選択保護リレ一動作への影響
}

$\begin{array}{lllll}\text { 正員 Suresh Chand Verma* } & \text { 正員 小川 } & \text { 重明* } \\ \text { 正員 高木 輝夫* } & \text { 非会員 桐田 } & \text { 雅行** } \\ \text { 非会員 片桐 徹** } & \text { 正員 松田 } & \text { 明洋*** } \\ \text { 正員 河野 良之㳥* } & & & \end{array}$

\section{Effect of Offshoot Branch Connected Rotary Machines on Line Selection Protection Relay}

Suresh Chand Verma*, Member, Shigeaki Ogawa*, Member, Teruo Takagi*, Member, Masayuki Kirita**, Non-member, Tooru Katagiri**, Non-member, Akihiro Matsuda***, Member, Yoshiyuki Kohno***, Member

The purpose of this paper is to study an effect of offshoot branch connected rotary machines on a line selection protection relay. The motivation for this study stems from the fact that in a real power system with offshoot branch containing rotary machines like synchronous generators and induction motors, a case of mal-tripping of a line selection relay was observed. The main cause of this mal-tripping was thorough investigated through digital simulation followed by experimental verification carried out by connecting a real time simulator to the real world relay. It is found that the mal-operation of the relay was triggered by the combined dynamic characteristics of the rotary machines like synchronous generators and induction motors. Hence, the main result of this paper is that in case of a power system with an offshoot branch containing induction motors in addition to generators, it is very important to consider their combined dynamic characteristics in true sense, which hitherto has been more or less limited to generators only while conducting such relay settings/studies.

キーワード：分岐系統，回線選択保護リレー，同期機，誘導電動機，リアルタイムシュミレータ

Keywords: power system with an offshoot branch, line selection protection relay, synchronous machine, induction motor, real time simulator

\section{1. まえがき}

電力系統の並行 2 回線送電線の保護リレー方式に短絡回 線選択保護リレー (以下 SS リレーと言う) がある。SS リ レーは, 内部故障時において, 回線間電流がアンバランス になることを利用して故障回線を検出するもので, アンバ ランス要素となりうる分岐系統が存在する場合にも適用さ れるが, この場合の SS リレー動作検討においては, 分岐 部に連系している発電設備特性のみを考慮しているのが一

\footnotetext{
*中部電力 (株) 電力技術研究所

T 459-8522 名古屋市緑区大高字北関山 20-1

Chubu Electric Power Co., Inc.

20-1, Kitasekiyama, Ohdaka-cho, Midori-ku, Nagoya 459-8522

** 中部電力 (株) 名古屋系統運用センター

干 460-8310 名古屋市中区干代田 2-12-14

Chubu Electric Power Co., Inc.

2-12-14, Chiyoda, Naka-ku, Nagoya 460-8310

*** 三菱電機 (株) 社会 e ソリューション事業所

干 652-8555 神戶市兵庫区和田崎町 1-1-2

Mitsubishi Electric Co., Inc.

1-1-2, Wadasaki-cho, Hyougo-ku Kobe 652-8555
}

般的である。

しかし，弚のようなリレー動作値の整定による対策を講 じていても，実際に，需要家設備が分岐連系している $77 \mathrm{kV}$ 系統において, 該当送電線の外部短絡故障により SS リレー が不要動作した例がある。現実系統において発生した SS リレー不要動作について, 光の再発を防止するため, 発生 要因の究明が必要である。

そこで本論文では, 分岐系統に連系している回転機とし て, 同期機と誘導電動機を取り上げ, 关の動特性を考慮して SS リレー動作への影響を検討した。検討においては, 瞬時 值解析と実機 SS リレーを用いた試験を行い, 弚の結果，一 般的にSS リレー動作検討で考慮していない誘導電動機負 荷が, SS リレー動作に影響を与えていることが明確になっ た。ここでは, 弚の概要を示す。

\section{2. 対象系統, 機器}

〈2: 1〉対象系統検討に用いた系統は, 現実に外部故 障時によりSS リレーが不要動作した系統を用いた。炎の 簡略系統図を図 1 に, 送電線定数を表 1 に示す。 
この系統において外部故障が発生すると，分岐連系する 回転機からも短絡電流が供給されるが, 光の一部は $\mathrm{B} \mathrm{s} / \mathrm{s}$ 母 線を経由して流れる。この B s/s 母線を経由して流れる短 絡電流は, 回転機の容量が大きいほど大きく，また分岐系 統が B s/s 至近であるほど大きくなる。乥れに伴い B s/s の 回線間電流アンバランスも大きくなり，SS リレーの不要動 作が発生しやすくなる。

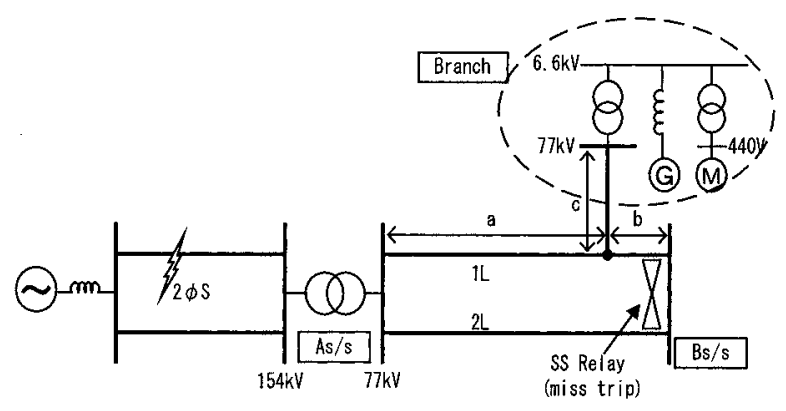

図 1 対象系統図 (概略図)

Fig. 1. Schematic diagram.

表 1 送電線定数

Table 1. Line constant.

\begin{tabular}{|c|c|c|}
\hline Line & $\% Z_{\ldots}$ 10MVAbase & $(\%)$ \\
\hline $\mathrm{a}$ & j 0.412 & \\
\hline b & j 0.014 & \\
\hline $\mathrm{c}$ & j 0.092 & \\
\hline
\end{tabular}

〈2. 2〉回転機の短絡電流特性回転機である同期機, 誘導機は, 3 相短絡故障発生時に短絡電流を供給するが, 図 $2^{(1)}$ に示すように，光の樣相は異なる。同期機は外部よ り励磁されているため, 過渡現象収束後も持続的に短絡電 流を供給するのに対し，誘導機は 3 相短絡故障に伴う電圧 低下により回転磁界の磁束か数サイクル程度で無視しうる 値まで咸衰するのが一般的である。ただし，2 相短絡故障時 は, 誘導機も持続的に短絡電流供給を行うこととなり，同 期機同樣に影響が大きい。

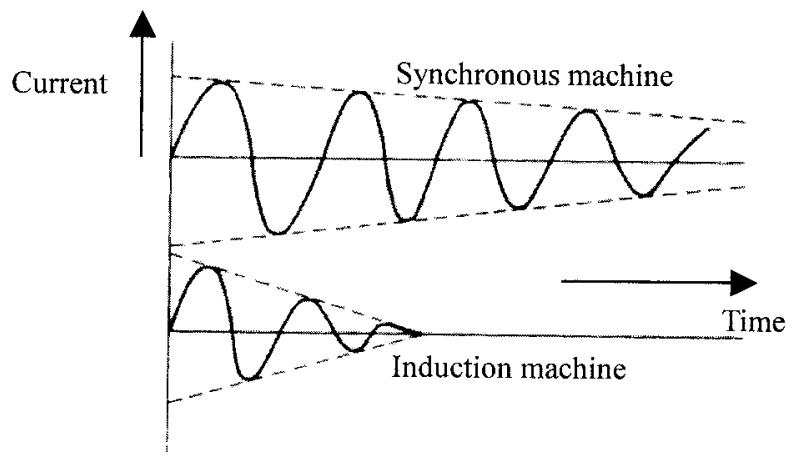

図 2 同期機, 誘導機の短絡電流

Fig. 2. Short circuit current of synchronous machine and induction machine.

\section{SSリレー特性}

〈3. 1〉SS リレー特性ＳS リレーにおいて, 主保護リ レー要素である 50S (短絡選択リレー)，50SA（50S 用過 電流リレー) の特性を以下に示す。

(1) $50 \mathrm{~S}$ 図 3 (a) に示すモ一特性において , 各相の回 線間差電流と電圧から求まる事故点インピーダンス $(\mathrm{Z})$ が 円内に入ったときに動作する。150S は $1 \mathrm{~L}$ 回線用 , 250S は 2L 回線用を示す。

(2) 50SA 図 3 (b) に示す特性図において, 各相の回 線間差電流 (I) が整定值以上流れたときに動作する。

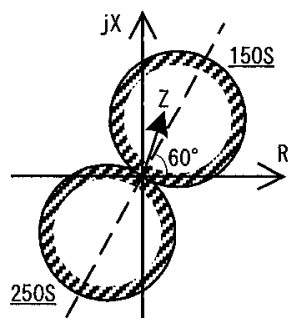

(a) $50 \mathrm{~S}$

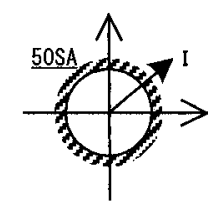

(b) 50SA
図 $350 \mathrm{~S}, 50 \mathrm{SA}$ 動作特性, シーケンス

Fig. 3. Operating characteristic of 50S and 50SA.

〈3. 2〉SS リレーシーケンス SS リレーは, 図 4 の シーケンスに示すように，50S，50SA 動作を条件に内部短 絡故障判定を行い, 高速度遮断する。

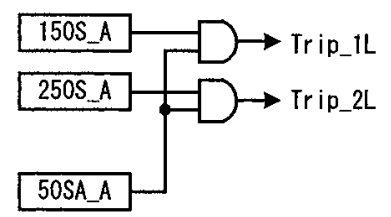

図 4 SS リレーシーケンス (A 相)

Fig. 4. SS relay sequence (phase A).

\section{4. 回転機による SSリレー動作への影響検討}

瞬時値解析と実機 SS リレーを用いた試験により，分岐 系統に連系した同期機，誘導電動機による SS リレーへの 影響を確認する。

〈4 1〉 シミュレーション( 瞬時值解析, 試験) 条件 シ ミュレーション対象系統は, 図 1 および表 1 に示した系統 を用いた。故障は, $154 \mathrm{kV}$ 線路短絡故障 $(3 \phi \mathrm{S}, 2 \phi \mathrm{S}[\mathrm{C}-\mathrm{A}$ 相]）とし,シミュレーション開始後 $0.1 \mathrm{sec} て ゙$ 発生させた。 また , 4 サイクル遮断を模擬した。

同期機については, 表 2 に示す小容量機を 3 台模擬し (合 計 18.9 MVA)，実系統と同じ機器定数を用いた。誘導電動 機については, $440 \mathrm{~V}$ 機を $2.7 \mathrm{MW}$ ずつ集約して 3 箇所に 模擬し（合計 8.1 MW), 機器定数はメーカー提示値の一例 を用いた。

$\mathrm{B} \mathrm{s} / \mathrm{s}$ の SS リレー整定值は表 4 に示す値を用いた。50SA 
整定値は，整定指針で規定した内部故障時の両端同時動作 範囲を確保した上で，外部故障時において分岐系統の同期 機から供給される故障電流でSS リレーが動作しないよう， 1.7 A とした。

\section{表 2 同期機定数}

Table 2. Parameters of synchronous machine.

\begin{tabular}{|l|c|}
\hline Synchronous machine & G \\
\hline \hline Rated voltage (V) & 6600 \\
\hline Rated capacity (MVA) & 6.3 \\
\hline $\mathrm{Xd}$ " (pu) & 0.25 \\
\hline
\end{tabular}

\section{表 3 誘導電動機負荷}

Table 3. Power output of induction motor load.

\begin{tabular}{|l|c|}
\hline Induction machine & M \\
\hline \hline Rated voltage (V) & 440 \\
\hline Total power output (MW) & 8.1 \\
\hline
\end{tabular}

表 4 SS リレー整定値 (2 次換算値)

Table 4. Setting value of SS relay.

\begin{tabular}{|c|c|}
\hline Relay & Setting value \\
\hline \hline $50 \mathrm{~S}$ & $10.2(\mathrm{ohm})$ \\
\hline $50 \mathrm{SA}$ & $1.7(\mathrm{~A})$ \\
\hline
\end{tabular}

〈4 2〉 瞬時值解析結果 瞬時値解析結果を, $3 \phi \mathrm{S}$ 時と $2 \phi \mathrm{S}$ (CA 相) 時に分けて, 表 5 , 表 6 に示す。また, 解析結 果の波形を図 5 (=No.1A), 図 6 (=No.4A), 図 7 (=No.4B) に示す。

図 5〜図 7 の (a) は模擬した同期機 3 台のうち 1 台 (6.3 MVA) が供給する電流，(b) は誘導機 (2.7 MW 分) が 供給する電流 $(6.6 \mathrm{kV}$ 側換算)，(c)(d) は, 対象の SS リレー がある B s/s の電圧と回線間差電流である。(e) は回線間差 電流 (2 次側) の実効値であり，50SA の応動を確認する。 (f) は故障時インピーダンスローカス図であり，50S の応動 を確認する。

表 5 瞬時値解析結果 ( $3 \phi S$ 時)

Table 5. Simulation result at $3 \phi \mathrm{S}$.

\begin{tabular}{|c|c|c|c|c|c|c|c|}
\hline \multirow{2}{*}{ No. } & \multicolumn{3}{|c|}{ Condition } & \multicolumn{4}{c|}{ Result } \\
\cline { 2 - 8 } & $\mathrm{G}$ & $\mathrm{M}$ & Fault & $250 \mathrm{~S}$ & $50 \mathrm{SA}$ & $\begin{array}{c}\text { SS } \\
\text { relay }\end{array}$ & ref. \\
\hline \hline 1A & 18.9 & - & $3 \phi \mathrm{S}$ & $\mathrm{ON}$ & - & - & Fig.5 \\
\hline $2 \mathrm{~A}$ & 18.9 & 2.7 & $3 \phi \mathrm{S}$ & $\mathrm{ON}$ & - & - & \\
\hline $3 \mathrm{~A}$ & 18.9 & 5.4 & $3 \phi \mathrm{S}$ & $\mathrm{ON}$ & - & - & \\
\hline $4 \mathrm{~A}$ & 18.9 & 8.1 & $3 \phi \mathrm{S}$ & $\mathrm{ON}$ & $\mathrm{ON}$ & $\begin{array}{c}\text { miss } \\
\text { trip }\end{array}$ & Fig.6 \\
\hline
\end{tabular}

$\mathrm{G}$ : Synchronous machine (MVA)

$\mathrm{M}$ : Induction motor (MW)
(1) $3 \phi \mathrm{S}$ 時 $3 \phi \mathrm{S}$ 時の瞬時値解析結果を表 5 に示 す。解析結果波形を図 5 , 図 6 に示す。

図 5(f)に示すように，誘導電動機負荷が無い場合におい ても故障時インピーダンスが $250 \mathrm{~S}$ の動作円内にあり，250S は動作する。つまり, 同期機（=18.9 MVA）が供給する故 障電流により，B s/s の 250S は外部故障で動作する。なお 表中には示していないが, 同期機 2 台 (=12.6 MVA) 以下 では，250S は動作しなかった。

No.1A〜No.3A では , 50SA は動作しないため , 50S のス トッパーとなり，SS リレー不要動作には至らない。誘導電 動機負荷が 8.1 MW に増えた No.4A では, 図 6(e) が示す ように50SA の整定值 $(=1.7 \mathrm{~A})$ 以上の回線間差電流が流 れ，50SA 動作により SS リレー不要動作に至った。No.4A については, $\langle 4 \cdot 3\rangle$ 節でさらに詳しく述べる。

(2) $2 \phi \mathrm{S}$ 時 $2 \phi \mathrm{S}$ 時の瞬時值解析結果を表 6 に示 す。解析結果波形を図 7 に示す。

$3 \phi \mathrm{S}$ 時と同樣に，誘導電動機負荷が無い場合においても， 同期機（=18.9 MVA） が供給する故障電流により $250 \mathrm{~S}$ は 外部故障で動作する。

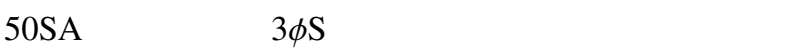
ることにより動作する。しかしながら， $2 \phi \mathrm{S}$ 時においては， 誘導電動機負荷が $5.4 \mathrm{MW}$ とした No.3B においても 50SA が動作し，SS リレー不要動作に至った。これは, 回線間差 電流の減衰の速さか関係しており，この回線間差電流の減 衰の違いは誘導電動機の影響と考えられる。図 6 , 図 7 の (e)を比較して分かるように，図6(e) では回線間差電流の 減衰が速いのに対し, 図 7(e) では減衰が遅い。これは, (b) に示したように,誘導電動機部に流れる電流の周期が, $3 \phi \mathrm{S}$ 時と $2 \phi \mathrm{S}$ 時で異なっており， $2 \phi \mathrm{S}$ 故障中では，同期機と誘 導電動機の供給する故障電流の周期がほぼ同じであるため， 回線間差電流の減衰が遅くなっている。

回線間差電流が整定値を越えるだけではなく，光の減衰 の速さ，つまり時定数がリレーの動作判定に関係している。 その理由は, 系統のサージ・ノイズ等の影響により, リレー か誤動作信号を出す可能性があるため, リレー動作判定に おいては, 弚の信頼性を高めるための処理として, サンプ

表 6 瞬時値解析結果 $(2 \phi \mathrm{S}$ 時)

Table 6. Simulation result at $2 \phi \mathrm{S}$.

\begin{tabular}{|c|c|c|c|c|c|c|c|}
\hline \multirow{2}{*}{ No. } & \multicolumn{3}{|c|}{ Condition } & \multicolumn{4}{c|}{ Result } \\
\cline { 2 - 8 } & $\mathrm{G}$ & $\mathrm{M}$ & Fault & $250 \mathrm{~S}$ & $50 \mathrm{SA}$ & $\begin{array}{c}\text { SS } \\
\text { relay }\end{array}$ & ref. \\
\hline 1B & 18.9 & - & $2 \phi \mathrm{S}$ & $\mathrm{ON}$ & - & - & \\
\hline 2B & 18.9 & 2.7 & $2 \phi \mathrm{S}$ & $\mathrm{ON}$ & - & - & \\
\hline 3B & 18.9 & 5.4 & $2 \phi \mathrm{S}$ & $\mathrm{ON}$ & ON & $\begin{array}{c}\text { miss } \\
\text { trip }\end{array}$ & \\
\hline 4B & 18.9 & 8.1 & $2 \phi \mathrm{S}$ & ON & ON & $\begin{array}{c}\text { miss } \\
\text { trip }\end{array}$ & Fig.7 \\
\hline
\end{tabular}

$\mathrm{G}$ : Synchronous machine (MVA)

$\mathrm{M}$ : Induction motor (MW) 


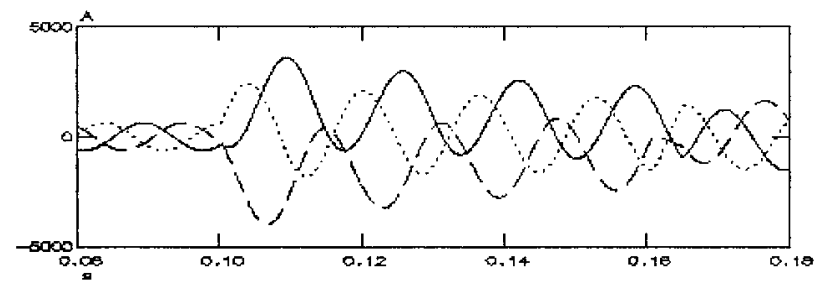

(a) Current from synchronous machine 6.3 MVA at branch

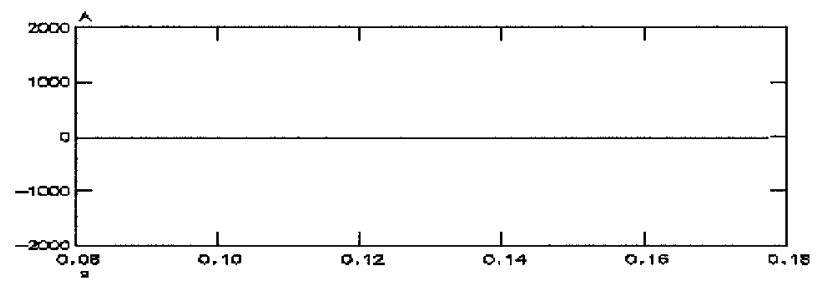

(b) Induction motor [Not connected]

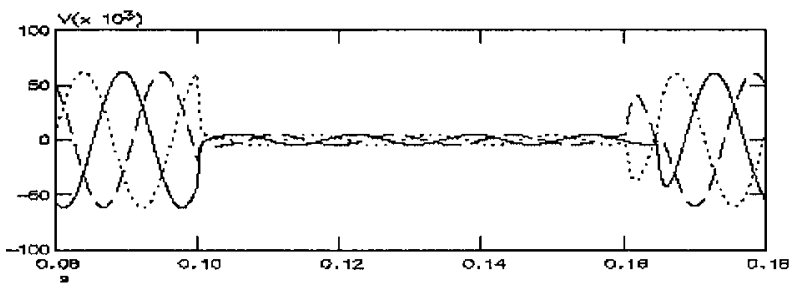

(c) Voltage at B s/s

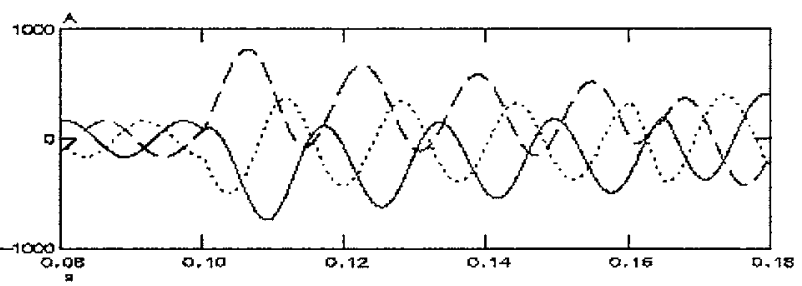

(d) Differential instantaneous current between lines at B s/s

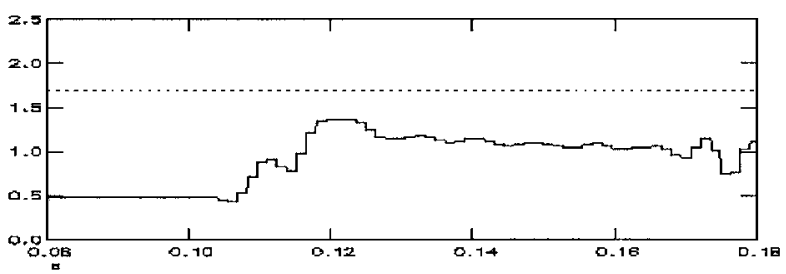

(e) Differential actual current between lines at B s/s (CT conversion, phase A)

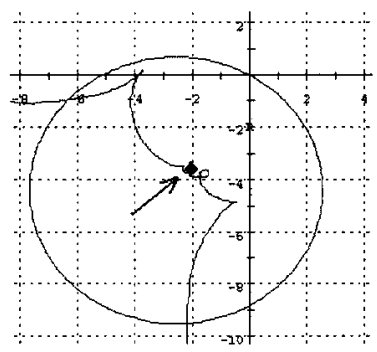

(f) Impedance locus at fault (phase A)

図 5 瞬時値解析波形 (No.1A)

Fig. 5. Waveform of simulation result (No.1A).

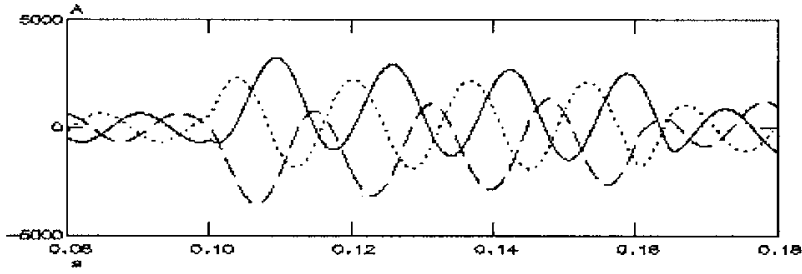

(a) Current from synchronous machine 6.3 MVA at branch

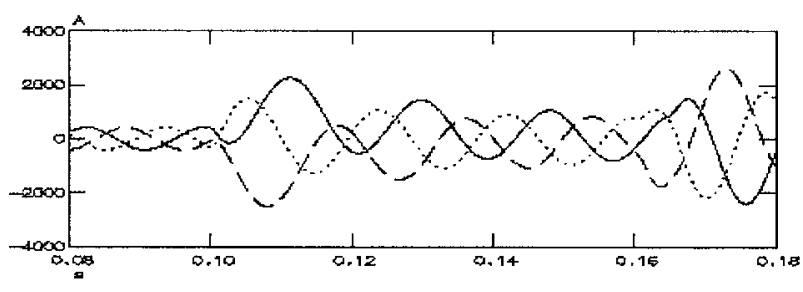

(b) Current from induction motor $2.7 \mathrm{MW}(6.6 \mathrm{kV})$ at branch

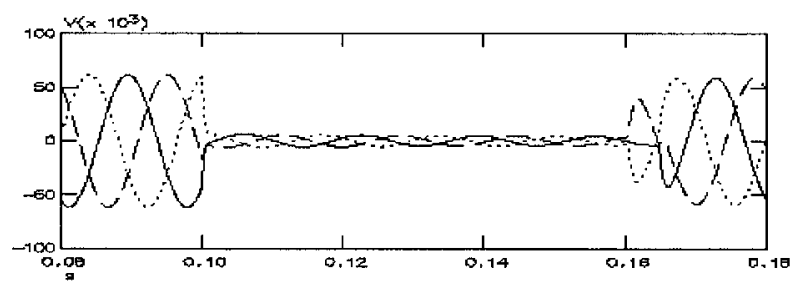

(c) Voltage at B s/s

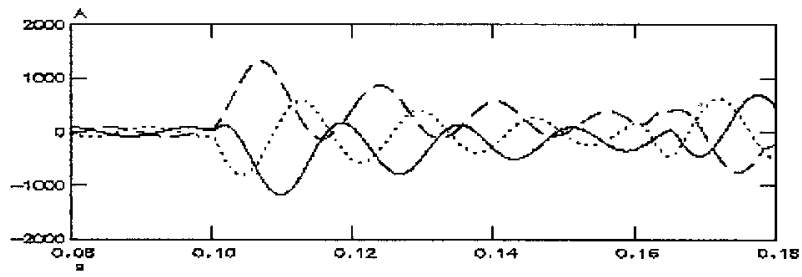

(d) Differential instantaneous current between lines at B s/s

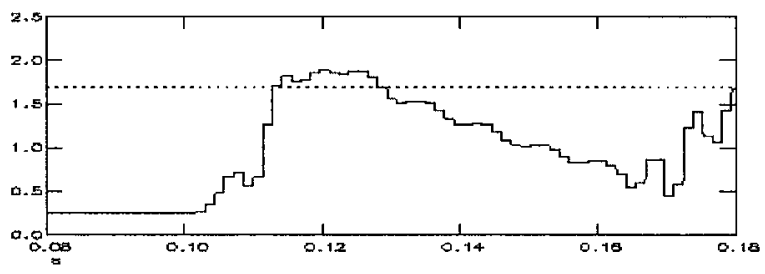

(e) Differential actual current between lines at B s/s (CT conversion, phase $\mathrm{C}$ )

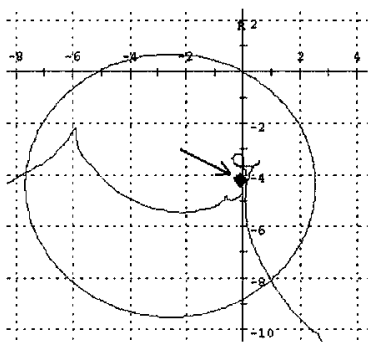

(f) Impedance locus at fault (phase A)

图 6 瞬時值解析波形 (No.4A)

Fig. 6. Waveform of simulation result (No.4A). 


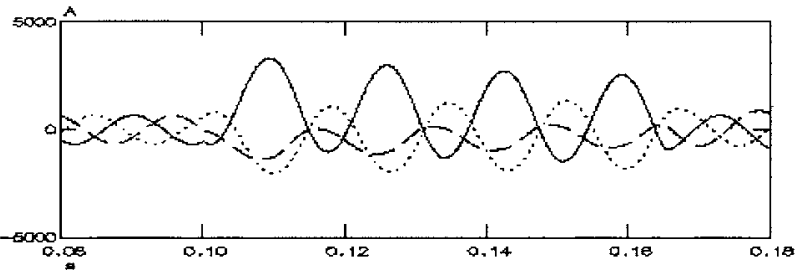

(a) Current from synchronous machine 6.3 MVA at branch

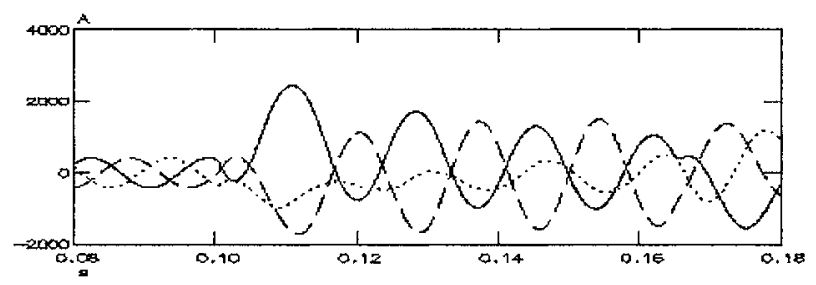

(b) Current from induction motor $2.7 \mathrm{MW}(6.6 \mathrm{kV})$ at branch

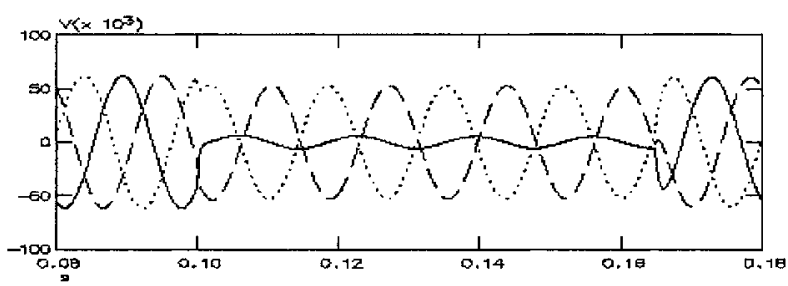

(c) Voltage at B s/s

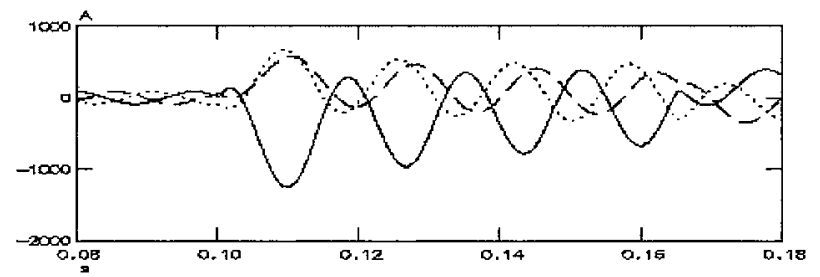

(d) Differential instantaneous current between lines at B s/s

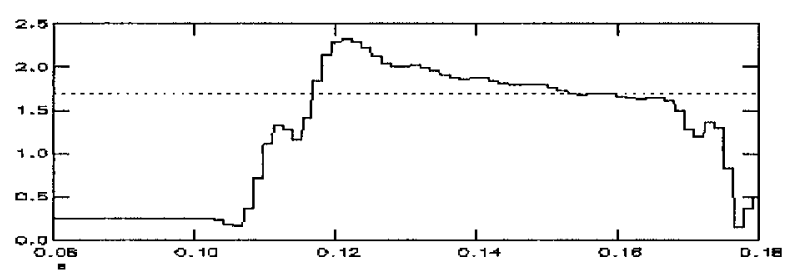

(e) Differential actual current between lines at B s/s (CT conversion, phase A)

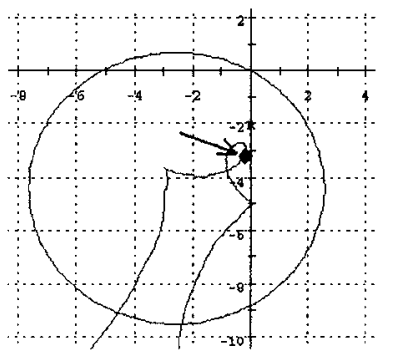

(f) Impedance locus at fault (phase A)

図 7 瞬時値解析波形 (No.4B)

Fig. 7. Waveform of simulation result (No.4B).
リング周期毎の結果が複数回連続動作することによって最 終判定としているためである。つまり，50 SA は整定值以 上の回線間差電流が一瞬ではなく，一定の時間を継続して 流れたときに動作判定することになる。以上より $2 \phi \mathrm{S}$ 時の 方が, $3 \phi \mathrm{S}$ 時よりも回線間差電流の時定数が大きいため, 少ない容量の誘導電動機が連系された場合で, SS リレーが 不要動作する可能性が高いことになる。

なお図 7(c) に示す B s/s の電圧波形において，2 相の電 圧が残っているが，これは A s/s の主変トランスが Y- $\Delta$ 結 線のためである。

〈4 3〉実機 SS リレーを用いた試験による検証実 機 SS リレーにおける動作確認を行うため, リアルタイム 系統解析シミュレータと実機 SS リレーを接続して動作試 験を行った。光の概念図を图 8 に示す。計算時間刻みは， $330 \mu \sec て ゙$ でった。

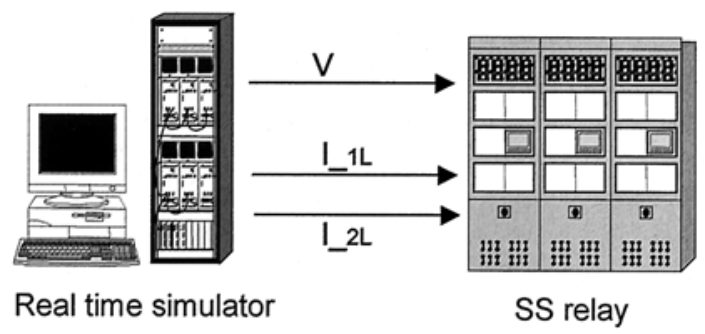

図 8 試験概念図

Fig. 8. Schematic diagram.

接続試験では, 表 5 , 表 6 に示した瞬時値解析結果と同 じ動作結果を得た。つまり，実機 SS リレーにおいて，外 部故障時の不要動作を確認した。

しかしながら，No.4A については，表 7 の瞬時值解析 case(a) と実機 SS リレーを用いた接続試験の結果に示すよ うに，250S の動作結果は一致（3 相動作）したが，50SA の動作相が異なった。つまり，瞬時值解析 (a) では, B 相 と C 相か動作したが，実機リレーは B 相のみが動作した。 この相違について, 故障発生タイミング (故障発生位相) を変えた場合の瞬時値解析を case(b) として加え，図 9 に

表 7 シミュレーションにおけるリレー動作時間 (No.4A)

Table 7. Simulation result of operating time (No.4A).

\begin{tabular}{|c|c|c|c|c|c|}
\hline \multirow{3}{*}{ Ref. } & \multirow{3}{*}{ Relay } & \multirow{3}{*}{ Phase } & \multicolumn{3}{|c|}{ Operating time $\quad(\mathrm{ms})$} \\
\hline & & & \multicolumn{2}{|c|}{$\begin{array}{c}\text { Digital } \\
\text { simulation }\end{array}$} & \multirow{2}{*}{$\begin{array}{l}\text { Real world } \\
\text { SS relay }\end{array}$} \\
\hline & & & Case (a) & Case(b) & \\
\hline \multirow{7}{*}{ No.4A } & \multirow{3}{*}{$250 \mathrm{~S}$} & A & 30.7 & 29.6 & 27.9 \\
\hline & & $\mathrm{B}$ & 27.9 & 31.0 & 25.2 \\
\hline & & $\mathrm{C}$ & 25.1 & 28.2 & 26.6 \\
\hline & \multirow{4}{*}{ 50SA } & $\mathrm{A}$ & - & 25.4 & - \\
\hline & & $\mathrm{B}$ & 23.8 & - & 25.2 \\
\hline & & $\mathrm{C}$ & 25.1 & - & - \\
\hline & & Ref. & Fig.9(a) & Fig.9(b) & - \\
\hline
\end{tabular}


case(a)(b)における回線間差電流と 50SA 動作結果を示し， 説明する。

表 7 および図 9 に示すように, case(b) では，50SA は A 相のみか動作し, case(a) と異なる結果となった。case(a)(b) とも全ての相は $50 \mathrm{SA}$ 整定値 $(=1.7 \mathrm{~A})$ 以上の電流が流れ ているが，動作判定していない相がある。これらの相が不 動作となったのは，50SA 整定值以上の電流が継続する時 間が短く，最終判定に至らなかったためである。このこと より，No.4A の条件は，3 $8 \mathrm{~S}$ で50SA が動作するか動作し ないかの境界付近であり，故障発生タイミングによって動 作相は変わると考えられる。

以上より，接続試験の結果は，表 5 , 表 6 に示した瞬時 値解析と同じ動作結果を得ており，ほぼ一致していると言 える。
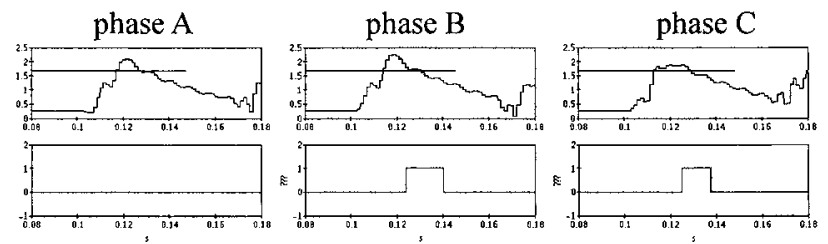

case (a)
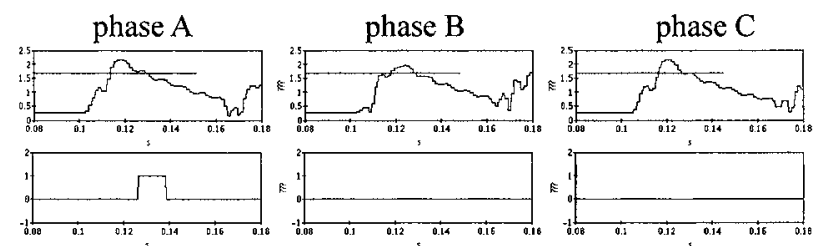

case (b)

図 9 No.4A における B s/s 回線間差電流 (実効值，CT2 次值) と 50SA 動作

Fig. 9. Differential actual current between lines (CT conversion) and 50SA operation at $\mathrm{B} \mathrm{s} / \mathrm{s}[\mathrm{No} .4 \mathrm{~A}]$.

\section{5. まとめ}

分岐系統に連系した需要家設備の回転機として同期機と 誘導電動機を取り上げ，SS リレーに及ぼす影響を検討した。

同期機が供給する故障電流により，50S か動作する場合 があるが， 50S のストッパーである 50SA の整定は，同期 機の Xd" を考慮して検討されているのが一般的であり，SS リレー不要動作には至らない。しかしながら，誘導電動機 負荷が比較的多く加わつた場合, 誘導電動機が供給する故 障電流の時定数は一般的に短いが, $50 \mathrm{SA}$ 動作に影響し，SS リレー不要動作に至る可能性があることを確認した。また， $2 \phi \mathrm{S}$ 時においては電圧不平衡となり， $3 \phi \mathrm{S}$ 時とは異なる樣 相となることを確認した。

今後の SS リレ一動作検討においては,誘導電動機の容量 や時定数などを考慮することか望ましい。整定指針で規定 した内部故障時の両端同時動作範囲を確保した上で, 50SA 整定値を大きくすることが，外部故障時の SS リレー不要 動作対策の一つとなる。ただし，SS リレー保護区間内故障
時に, 両端同時動作の範囲が縮小 (シリーズトリップ範囲 が拡大) することになり，注意が必要である。

(平成 16 年 2 月 24 日受付, 平成 16 年 6 月 14 日再受付)

\section{文献}

（1）電気学会 : 新版 工場配電, p.69 (1989)

(2) K.-H. Tseng, W.-S. Kao, and J.-R. Lin: "Load Model Effects on Distance Relay Settings", IEEE Trans. Power Delivery, Vol.18, No.4, pp.1140-1146 (2003)

Suresh Chand Verma (正員) 1986 年インド Roorkee 大学大学院

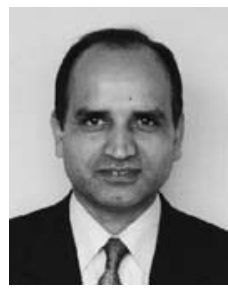
工学研究科電気工学専攻修了。インドにて電力会 社勤務。1990 年来日。1994 年名古屋工業大学大 学院工学研究科電気工学専攻博士課程修了。同年 4 月中部電力 (株) 入社。現在同社電力技術研究 所に所属。主に電力系統の解析技術に関する研究 に従事。

小 川 重 明 (正員) 1964 年四日市工業高等学校電気科卒業。

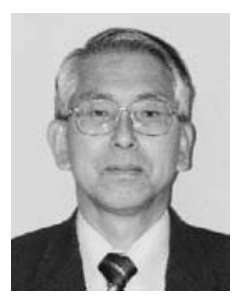
同年 4 月中部電力 (株) 入社。主として電力系統 の給電指令制御，系統保護計画・運用に従事。現 在同社電力技術研究所系統チームリーダー。

高 木 輝 夫 (正員) 1996 年 3 月大阪大学工学部電気工学科

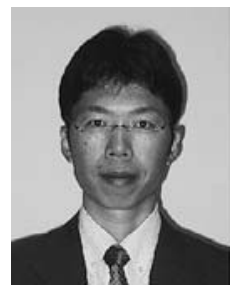
卒業。同年 4 月中部電力 (株) 入社。主として電 力系統の給電制御，系統保護整定に従事。現在同 社電力技術研究所に所属。主に電力品質に関する 研究に従事。

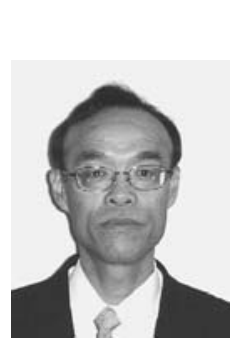

(非会員) 1955 年生。1974 伊勢工業高等学校電 気科卒業。同年 4 月中部電力 (株) 入社。主とし て電力系統の保護計画・運用, 保護装置の工事に 従事。現在同社名古屋系統運用センターに所属。 主に系統技術業務に従事。

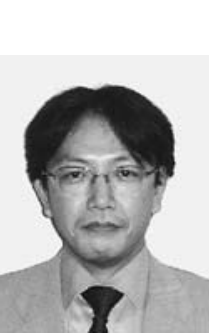

(非会員) 1968 年生。1986 東山工業高等学校電 気科卒業。同年 4 月中部電力 (株) 入社。主とし て電力系統の給電指令制御，保護運用，保護装置 の工事に従事。現在同社名古屋系統運用センター に所属。主に系統保護運用業務に従事。 
松田明洋 (正員) 1972 年生。1997 年 3 月横浜国立大学大 学院工学研究科修了。同年 4 月三菱電機 (株) に 入社。主として GIS , 保護リレーの開発設計, 系 統解析に従事。現在 , システムインテグレーショ ン部系統解析技術課に勤務。
河 野 良之 (正員) 1981 年神戶大学大学院 (電気・電子) 終了。 同年三菱電機 (株) 入社。以後, 系統解析, 系統 計画に関する研究に従事。現在, システムインテ グレーション部系統解析技術課課長。工学博士。 